Metode Qira Ah Muwahhadah Dalam Membentuk Keserasian..

\title{
METODE QIRA AH MUWAHHADAH DALAM MEMBENTUK KESERASIAN BACAAN AL QUR AN (STUDI KASUS DI PONDOK PESANTREN MADRASATUL QUR AN (MQ) TEBUIRENG JOMBANG)
}

\author{
Moch. Sya'roni Hasan ${ }^{1}$ \\ Lusmiyatun Nisa $^{2}$ \\ STIT al Urwatul Wutsqo Jombang \\ raisyaroni@gmail.com
}

\begin{abstract}
The implementation of the Qira ah Muwahhadah Method is expected to be able to form the reading of Al Qur an santri Madrasatul Qur an Tebuireng which were originally influenced by dialects from each region to be harmonious in accordance with the Qira ah standard taught by K.H.M. Yusuf Masyhar. Based on the background above, this thesis is focused on three aspects of description, namely: 1) learning planning of Qira ah Muwaḥhadah in Islamic Boarding School Madrasatul Qur an Tebuireng 2) the learning process of Qira ah Muwaḥhadah in Islamic Boarding School Madrasatul Qur an Tebuireng 3) evaluation of learning Qira ah Muwaḥhadah at the Islamic Boarding School Madrasatul Qur an Tebuireng. This study states that the implementation of the Qira ah Muwahhadah method includes: classical fas \} ah\} ah development, Al Qur'an payment, and Al Qur'an memorization. Evaluation of the learning of the Qur'an Qira ah Muwaḥhadah carried out as a whole, both evaluations that are formal (the Qur'anic test) which is carried out every 6 months and evaluations relating to the learning process of the Qur'an Qira ah Muwaḥadah every month. The results of the Qira ah Muwaḥhadah method at the Madrasatul Qur an Tebuireng Islamic Boarding School can form the Qur'anic readings of the students who were originally influenced by their respective regional dialects to be harmonious according to the Qira ah standard taught by K.H. M. Yusuf Masyhar, so that students of the Islamic Boarding School in Madrasatul Qur an Tebuireng can practice the reading of the Qur'an in their respective regions. Criteria for harmony in reading the Qur'an include: harmonious in the field of proficiency in saying makharijul $h$ \} uruf, harmonious in the practice of tajwid when reading the Qur'an and be harmonious in rhythm or song when chanting the verses of the Qur'an.
\end{abstract}

Keywords: Qiroah Muwahhadah Method, reading harmony

\begin{abstract}
Abstrak
Implementasi Metode Qira ah Muwaḥhadah diharapkan dapat membentuk bacaan Al Qur an santri Madrasatul Qur an Tebuireng yang semula masih dipengaruhi dialek dari masing-masing daerah menjadi serasi sesuai dengan standart Qira ah yang diajarkan oleh K.H.M. Yusuf Masyhar. Berdasarkan latar belakang di atas maka skripsi ini difokuskan pada tiga aspek pendiskripsian yaitu: 1) perencanaan pembelajaran Qira ah Muwaḥhadah

\footnotetext{
${ }^{1}$ Dosen Prodi PAI STIT Al Urwatul Wutsqo Jombang.

${ }^{2}$ Guru SMP MQ tebuireng jombang

Falasifa, Vol. 10 Nomor 2 September $2019 \mid 102$
} 
di Pondok Pesantren Madrasatul Qur an Tebuireng 2) proses pembelajaran Qira ah Muwaḥhadah di Pondok Pesantren Madrasatul Qur an Tebuireng 3) evaluasi pembelajaran Qira ah Muwahhhadah di Pondok Pesantren Madrasatul Qur an Tebuireng. Penelitian ini menyatakan bahwa implementasi metode Qira ah Muwaḥhadah meliputi: pembinaan fas\}ahłah klasikal, setoran Al Qur an, dan pembinaan hafalan Al Qur an. Evaluasi pembelajaran Al Qur an Qira ah Muwaḥhadah dilaksanakan secara menyeluruh, baik evaluasi yang bersifat formal (ujian Al Qur an) yang dilaksanakan 6 bulan sekali maupun evaluasi yang berkaitan dengan proses pembelajaran Al Qur an Qira ah Muwaḥhadah setiap bulan. Hasil metode Qira ah Muwaḥhadah di Pondok Pesantren Madrasatul Qur an Tebuireng ini dapat membentuk bacaan Al Qur an para santri yang semula masih dipengaruhi oleh dialek daerah masing-masing menjadi serasi sesuai standart Qira ah yang diajarkan oleh K.H. M. Yusuf Masyhar, sehingga santri Pondok Pesantren Madrasatul Qur an Tebuireng bisa mengamalkan bacaan Al Qur an tersebut di daerahnya masing-masing. Kriteria keserasian dalam membaca Al Qur an tersebut meliputi: serasi dalam bidang kefashihan dalam mengucapkan makharijul hłuruf, serasi dalam praktek ilmu tajwid ketika membaca Al Qur an dan serasi dalam irama atau lagu saat melantunkan bacaan ayat-ayat Al Qur an.

Kata Kunci: Metode Qiroah Muwahhadah, keserasian bacaan.

\section{PENDAHULUAN}

Alquran sebagai petunjuk dan pedoman hidup bagi umat Islam. Berfungsi untuk menghantarkan dan membimbing manusia ke jalan yang lurus dalam mencapai kebahagiaan dunia dan akhirat. Untuk mencapai tujuan tersebut dibutuhkan ilmu-ilmu yang digunakan untuk mengkaji dan mempelajari isi dan kandungan Alquran tersebut. Keilmuan yang berhubungan untuk mengkaji isi kandungan Alquran tersebut antara lain: ilmu Nah'wu, Słorof, Tajwid, Tafsir, balaghoh, dan keilmuan lainnya. ${ }^{3}$

Allah SWT memberikan penghargaan bagi hambanya yang mau belajar dan mengajarkan Alquran. Dan mereka termasuk kategori golongan sebaik-baiknya manusia. Sebagaimana sabda Rasulullah SAW:

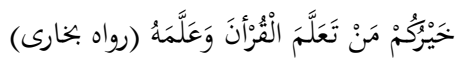

\section{Artinya: Sebaik-baik kamu adalah orang yang belajar Alquran dan} mengamalkannya (HR. Bukhori) ${ }^{4}$

Pembelajaran Alquran dimulai dengan belajar membaca huruf demi huruf, ayat demi ayat dari Alquran yang sesuai dengan ilmu musammayatul hłuruf, makhorijul $h\}$ uruf dan

\footnotetext{
${ }^{3}$ Manna Khalil Al Qattan, Studi Ilmu Ilmu Alquran (Bogor : Litera Antar Nusa, 2009), 9.

${ }^{4}$ Imam Al Nawawi, Mutiara Riyadhus Shalihin (Bandung: PT Mizan Pustaka, 2009), 577.
} 
Metode Qira Ah Muwahhadah Dalam Membentuk Keserasian...

ilmu tajwid dengan memakai lahjjah 'arabiah. Dipilihnya bahasa Arab sebagai penjelas dan petunjuk Allah SWT ini disebabkan Alquran diturunkan pertama kali pada masyarakat Arab yang memiliki keunikan bahasa dibanding dengan bahasa-bahasa yang lain. ${ }^{5}$

Kelebihan yang lain dari salah satu mu'jizat Nabi Muhammad SAW ini adalah kemudahan dalam mengkajinya. Sebagaimana firman Allah SWT:

"Dan sesungguhnya telah kami mudahkan Alquran untuk pelajaran, maka adakah orang yang mengambil pelajaran? (Q.S. Al Qomar: 17) ${ }^{6}$

Imam al-Jazari dalam muqoddimah kitabnya mengatakan: Suatu kewajiban bagi seorang qori' dalam membaca Alquran untuk lebih dahulu mengetahui ilmu atau seluk beluk jalan keluar suara huruf dan berbagai sifat-sifatnya agar mereka dapat membaca Alquran dengan baik dan benar. ${ }^{7}$

Dengan demikian proses awal dalam mempelajari Al quran (membaca) umat Islam harus mempunyai pengetahuan tentang ilmu tajwid. Karena dengan memperhatikan keilmuan dalam Alquran khususnya dari segi bacaannya, maka akan terbentuk bacaan yang indah dan enak didengar serta bacaan tersebut fas $\}$ ih\} dan benar.

Pembelajaran Alquran ini biasa dilakukan ketika seorang anak masih berusia relatif muda. Kebanyakan orang tua mengantar anak-anak mereka untuk belajar membaca Alquran di Taman Pendidikan Alquran (TPQ) yang dibimbing oleh ustadz atau ustadzah. Setiap daerah mempunyai cara penyampaian dan penjelasan keilmuan Alquran yang berbeda. Hal ini juga termasuk bagaimana seorang ustadz atau ustadzah dalam menyampaikan dasar-dasar pengucapan huruf Alquran (hijaiyah) yang berbeda pula. Karena hal ini dipengaruhi kemampuan penguasaan ilmu tajwid dan logat atau dialek daerah masing-masing.

Berdasarkan hal di atas, Almaghfurlah K.H.M. Yusuf Masyhar sebagai kyai dan pendiri Pondok Pesantren Madrasatul Qur an Tebuireng merumuskan sebuah metode pembelajaran Alquran yang diwujudkan dengan berdirinya sebuah lembaga pesantren yang diberi nama Madrasatul Qur an. Dengan di dasari pemikiran tentang metode pembelajaran Alquran yang telah diajarkan oleh Almaghfurlah K.H.M. Yusuf Masyhar yang sering

\footnotetext{
${ }^{5}$ M. Quraisy Syihab, Tafsir Al Misbah Pesan, Kesan dan Keserasian Alqur an (Jakarta: Lentera Hati, 2002), 392.

${ }^{6}$ Alquran dan Terjemahnya, ( Semarang: Thoha Putra,1995), 529.

${ }^{7}$ Imam Jazari, Jazariyah (Surabaya: Al Hidayah, 1991), 2.

Falasifa, Vol. 10 Nomor 2 September 2019| 104
} 


\section{Moch. Sya'roni Hasan}

Lusmiyatun Nisa

disebut dengan Qiro ah Muwaḥhadah. Metode pembelajaran ini dipraktekkan secara berkesinambungan oleh santri-santri beliau dari generasi satu ke generasi yang lain. Dengan tujuan agar keserasian bacaan santri Madrasatul Qur an Tebuireng tetap terjaga, baik di tinjau dari fas\}ah $\} a h$, tajwid dan iramanya.

Proses pembelajaran Alquran di Pondok Pesantren Madrasatul Qur an mempunyai tiga tahapan, yaitu pembelajaran binnadhar (membaca Alquran), tah\}fidh Alquran (menghafal Alquran) dan Qiro ah sab'ah (bacaan Alquran tujuh riwayat). Peneliti tertarik untuk membahas tentang tahapan pembelajaran binnadhar (membaca Alquran) khususnya metode pembelajaran Alquran Qiro ah Muwaḥhadah. Karena menurut peneliti tahapan ini sangat penting bagi umat Islam, khususnya bagi yang berminat dalam tahapan menuju tah ffidh Alquran (menghafal Alquran). ${ }^{8}$

Berdasarkan paparan di atas, penulis merasa perlu untuk membahas lebih mendalam tentang implementasi metode pembelajaran Alquran Qiro ah Muwaḥhadah di Pondok Pesantren Madrasatul Qur an Tebuireng . Karena tidak semua Pondok Pesantren yang berciri khas Alquran menerapkan standarisasi bacaan Alquran dalam proses menghafal Alquran. Atas dasar diatas peneliti mengangkat judul penelitian "Implementasi Metode Qiro ah Muwaḥhadah dalam Membentuk Keserasian Bacaan Alquran. (Studi Kasus di Pondok Pesantren Madrasatul Qur an Tebuireng). Berdasarkan latar belakang yang telah peneliti paparkan, maka fokus penelitian ini dapat dijelaskan sebagai berikut: Bagaimana perencanaan pembelajaran Qira ah Muwaḥhadah di Pondok Pesantren Madrasatul Qur an Tebuireng?, Bagaimana proses pembelajaran Qira ah Muwaḥhadah di Pondok Pesantren Madrasatul Qur an Tebuireng? Bagaimana evaluasi pembelajaran Qira ah Muwaḥhadah di Pondok Pesantren Madrasatul Qur an Tebuireng?

\section{METODE PENELITIAN}

Penelitian yang peneliti lakukan menggunakan penelitian jenis deskriptif. Tujuannya adalah untuk mendiskripsikan implementasi metode Qira ah Muwaḥhadah dalam membentuk keserasian bacaan Al Qur an di Pondok Pesantren Madrasatul Quran Tebuireng Jombang dengan menggali data secara transparan, sehingga dapat menganalisisnya sesuai apa adanya. Penelitian ini mendiskripsikan bagaimana

\footnotetext{
${ }^{8}$ Litbang MQ, Buku Panduan Santri Madrasatul Qur an Tebuireng, (MQ: Jombang, 2013), 8.
} 
Metode Qira Ah Muwahhadah Dalam Membentuk Keserasian...

perencanaan, proses, dan evaluasi pembelajaran Qira ah Muwaḥhadah sehingga menghasilkan output yang sesuai dengan tujuan visi dan misi Pesantren.

Adapun teknik pengumpulan data melalui tahap-tahap sebagai berikut: a. Wawancara. Metode wawancara adalah metode untuk mengumpulkan data-data dengan jalan tanya jawab sepihak yang dikerjakan secara sistematis dan berlandaskan pada penyelidikan. ${ }^{9}$ Data yang diperoleh dengan menggunakan metode wawancara ini akan digunakan untuk mendapatkan informasi yang akurat tentang metode Qira ah Muwahhadah dalam membentuk keserasian bacaan Al Qur an bagi santri Pondok Pesantren Madrasatul Qur an Tebuireng dari berbagai sumber antara lain: Bapak H. Abd. Hadi Yusuf, S.H., selaku Pengasuh, Bapak Ir. H. Abd. Ghoffar, selaku ketua Yayasan, H. A. Syakir Ridlwan, Lc, M. H.I, selaku mudir II bidang Al Qur an dan H. A. Hariri Shoheh, S. Ag, selaku Ustadz dan alumni Pondok Pesantren Madrasatul Qur an Tebuireng dan Asatidz serta santri yang lain. b. Pengamatan atau observasi. Teknik observasi perlu digunakan dalam penelitian ini, karena teknik observasi digunakan hampir pada seluruh proses pengumpulan data, termasuk ketika melakukan penjajakan awal sebelum dilakukan penyusunan proposal. Dengan melakukan observasi dimaksudkan agar dapat mengetahui dan memahami gambaran yang utuh tentang obyek penelitian dan dapat mendiskripsikan kegiatan-kegiatan pembelajaran Qira ah Muwaḥhadah yang dipraktekkan di Pondok Pesantren Madrasatul Qur an Tebuireng. c. Dokumentasi. Metode dokumentasi ini bertujuan untuk mendapatkan data yang akurat dan jelas tentang metode Qira ah Muwaḥhadah dalam membentuk keserasian bacaan Al Qur an bagi santri Pondok Pesantren Madrasatul Qur an Tebuireng.

Teknik analisa data merupakan proses mencari dan mengatur secara sistematis transkip wawancara, catatan lapangan dan bahan-bahan lain yang dipahami peneliti. Maka dapat dijelaskan bahwa pelaksanaan analisa data ini menggunakan beberapa prosedur sebagai berikut: Reduksi data (pemilahan data), reduksi dengan memilih data yang kredibel untuk dipakai, sedangkan data yang tidak kredibel dipotong atau dibuang. Display data (klasifikasi data), display dengan cara data kredibel yang telah diperoleh dipilah menjadi 3 bagian sesuai dengan fokus penelitian. Setiap fokus masalah kemudian diletakkan dalam map yang berbeda warna. Hal ini dilakukan untuk mempermudah

${ }^{9}$ Moleong, Metodologi Penelitian Kualitatif, 64.

Falasifa, Vol. 10 Nomor 2 September 2019| 106 


\section{Moch. Sya'roni Hasan}

\section{Lusmiyatun Nisa}

pengelompokan dan pengolahan data. Coding data (memberi kode), dengan cara mengkode informasi dalam bentuk tertentu. Data kredibel yang sudah dipilah dibeberapa map kemudian diberi kode atau sandi sesuai dengan fokus masalah. Pemberian kode yang akan dilakukan yaitu, kode "QM" untuk data yang berkaitan dengan Qira ah Muwaḥhadah dan kode "KB" untuk data keserasian bacaan Al Qur an.

Uji keabsahan data sangat perlu dilakukan agar data yang dihasilkan dapat dipercaya dan dipertanggung jawabkan secara ilmiah. Uji keabsahan melalui: Perpanjangan keikutsertaan, Ketekunan observasi, Triangulasi

\section{KAJIAN PUSTAKA.}

\section{A. Metode Qiro ah Muwah $\}$ h $\} a d a h$}

1. Pengertian dan ciri-ciri Qiro ah\} Muwaḥhadah

Menurut bahasa, Qiro at (قراءات) adalah bentuk jamak dari Qiro ah (قر اءة) yang merupakan isim masdar dari qara'a (قرأ), yang artinya: bacaan. Pengertian Qiro at menurut istilah adalah salah satu aliran dalam mengucapkan Alquran yang dipakai oleh salah seorang imam quro yang berbeda dengan yang lainnya dalam hal ucapan Alquran Al karim dan berdasarkan sanad-sanad yang sampai kepada Nabi Muhammad SAW. ${ }^{10}$

Sedangkan pengertian Qira ah Muwaḥhadah adalah qira ah yang diajarkan oleh K.H.M. Yusuf Masyhar (sebagai salah satu pendiri dan pengasuh pertama Pondok Pesantren Madrasatul Qur an Tebuireng) kepada para santrinya dengan merujuk kepada bacaan Asy syech Mahmud Kholil Al Khushory sebagai landasan standart fas \}ahah dan irama dalam mempelajari Alquran. ${ }^{11}$

Tujuan adanya metode Qira ah Muwaḥhadah ini adalah untuk menyerasikan bacaan Alquran santri Pondok Pesantren Madrasatul Qur an Tebuireng dari generasi awal berdirinya Pondok Pesantren Madrasatul Qur an Tebuireng sampai generasi sekarang ini, baik dari segi fas lahahnya, ilmu tajwidnya dan juga iramanya.

Sedangkan ciri-ciri Qira ah Muwaḥhadah yang diajarkan kepada santri Pondok Pesantren Madrasatul Qur an Tebuireng sebagai berikut:

\footnotetext{
${ }^{10}$ Muhammad Ali Ash-Shaabuuniy, Studi Ilmu Alquran (Bandung: Pustaka Setia, 1998), 374.

${ }^{11}$ H. A. Hariri Shoheh dkk, Panduan Ilmu Tajwid (Jombang: Unit Tahfidh, 2012), 1.
} 
1) Makharijul hłuruf

K.H.M. Yusuf Masyhar berijtihad untuk memberikan kriteria dalam masalah makharijul hłuruf, antara lain :

ش : tempat keluarnya di tengah-tengah lidah mengarah kepada langit-langit atas (jawa cethak) dengan menekankan keluarnya nafas secara merata di mulut dengan bentuk mulut tidak monyong (jawa : тесиси).

ض : tempat keluarnya di separuh lidah atau tepi lidah (kiri atau kanan) bertemu dengan gigi geraham bagian atas dengan tekanan suara atau bunyi yang memanjang (masih ada suara atau tidak langsung buntu atau habis dari lepasnya ض ض sampai sempurnanya melafalkan huruf.

ظ : tempat keluarnya, yaitu bertemunya ujung lidah dengan ujung gigi atas (dua ujung gigi depan) agak renggang dengan bentuk monyong (jawa : тесиси).

ذ : bertemunya ujung lidah dengan ujung gigi atas (dua ujung gigi depan) menempel (lebih dekat atau merapat) dengan bentuk mulut tidak mecucu.

ج : keluarnya di tengah-tengah lidah mengarah pada langit-langit atas, dengan lebih menampakkan sifat jahr-nya.

Keterangan: Selain lima huruf di atas, K.H.M. Yusuf Masyhar berpedoman pada ketentuan makharij al-h\}uruf dalam kitab "Jazariyah”

2) Sifatul hłuruf

Dalam hal sifatul h\}uruf hanya mengambil dua dari beberapa sifat yang ada, yaitu: hams (keluarnya nafas ketika mengucapkan huruf hijaiyyah) dan jahr (tidak keluarnya nafas ketika mengucapkan huruf hijaiyyah). Mengingat dengan dua sifat tersebut yang paling menentukan dalam kesempurnaan bacaan sebagai berikut :

\section{a) $\operatorname{Jahr}(ج)$}


\& (Hamzah) dalam menyembunyikan hamzah murni dengan suara A tidak masuk menyerupai pada huruf $\bullet$ atau $\tau$.

ج (Jim) untuk suara jim (jahrnya Jim) tekanannya adalah pada suara jim yang utuh, yaitu dari awal membunyikannya tidak ada rentang bunyi atau jarak yang mengikuti (udara tidak sampai keluar atau bocor).

b) Hams

Berdasarkan pada ke-hams-an dari huruf-huruf mahmusah diklasifikasikan sebagai berikut:
1. ش (shin)
6. s (kaf)
2. $\omega(\sin )$
7. $\quad ت\left(\mathrm{ta}^{\prime}\right)$
3. ص (s\}ad)
8. $\tau$ (ha)

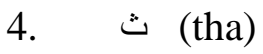
9. $\dot{\tau}$ (kha)
5. ف (fa')
10. ه (ha')

Keterangan: huruf yang bertashdid, mati atau yang berharakat tetap dibunyikan secara sempurna, seperti : و والسّماء = وس سماء dan tidak sampai bunyi و واليّماء =وس ئماء : hams-nya tertukar dengan huruf lain, seperti

\section{3) Ahjkamul hłuruf}

a) Ikhfa'

Pada waktu mendengungkan huruf yang pertama (nun mati atau tanwin) posisi lisan sudah menempati makhrojnya salah satu huruf ikhfa' yang akan dibaca.

Dalam praktek membaca $i k h f a$ ' di bagi menjadi tiga bagian, yaitu:

1. Aqrob (dekat) adalah bacaan ikhfa' yang lebih dekat dengan idhar, yaitu membacanya seperti idhar tetapi disertai dengan dengung sehingga bacaan tersebut menjadi samar. Adapun hurufnya ada tiga (ت منتهون : contoh : ينطقون دكادكا

2. Ab'ad (jauh) adalah bacaan ikhfa' yang lebih jauh dari idhar, yaitu ketika membaca sangat tampak dengungnya atau samarnya, sehingga suara nun mati 
Metode Qira Ah Muwahhadah Dalam Membentuk Keserasian...

atau tanwin menjadi hilang sama sekali. Adapun hurufnya ada dua yaitu s من قبل منك Contoh. ق م

3. Ausat\} (tengah-tengah) adalah bacaan ikhfa' pertengahan antara ikhfa' aqrob dan ikhfa' ab'ad dalam hal kesamaran membacanya. Adapun hurufnya ada satu من فضل الله Contoh

4) Waqaf dan Washal

a) Waqaf

Pada dasarnya waqaf diakhir ayat adalah boleh atau sah dan tidak ada masalah. Akan tetapi pada ayat- ayat tertentu K.H. M. Yusuf Masyhar lebih memilih waqaf pada kalimat yang dapat di mengerti artinya.

\section{b) Washal}

Pada ayat terakhir surat Al Fatihah K.H. M. Yusuf Masyhar lebih memilih dibaca sambung (was $\} a l$ ) dengan alasan masih ada hubungan dalam arti dari ayat tersebut.

5). Mad Wajib panjangnya adalah 5 harakat (2,5 alif), misalnya: جآء شآ،

Mad Ja'iz: Panjangnya lebih panjang dari pada mad tabi'i dan tidak boleh sama atau lebih panjang dari pada mad wajib, maksimal 2 alif (4 harakat), misalnya: ياآيها الَّين أمنوا، وماً أمروا. Pilihan K.H.M. Yusuf Masyhar bacaan mad jaiz tetap di baca panjang.

\section{6). Qalqalah}

1. Huruf qalqalah yang ganda (dobel) ketika waqaf tetap dibaca sempurna, misalnya بالحقّ

2. Huruf qalqalah yang jatuh setelah huruf mati (sukun) ketika waqaf huruf عذاب الخلا، لله الحمد، : qalqalah tetap dibaca dengan sempurna, misalnya

3. Huruf qalqalah yang jatuh setelah huruf yang mati, dan huruf tersebut adalah huruf qalqalah pula, maka ketika waqaf huruf qalqalah yang pertama dibaca sempurna dan meraumkan (tidak sempurna) huruf qalqalah yang kedua, misalnya ; نعم العبد

Falasifa, Vol. 10 Nomor 2 September 2019| 110 
Dari segi suara, qalqalah yang mati seperti ada unsur hamzahnya, mesti ada, tetapi bukan suara hamzah melainkan pantulan dari huruf qalqalah yang mati tadi.

\section{7). Waqaf pada dua huruf mati (raum)}

Ketika waqaf pada huruf berharakat yang sebelumnya berupa huruf mati maka cara membacanya adalah dengan memperjelas sifat huruf yang pertama dan menyedikitkan sifat huruf yang kedua. Contoh: meraumkan huruf $(J)$ pada lafaz (و والفجر)

Keterangan: dianggap satu huruf terakhir tidak hilang jika pembaca tetap merasakan sendiri, tanpa dikeluarkan (disuarakan dengan jelas).

\section{8). Tawallud}

Yaitu mengeluarkan bunyi huruf yang mati selain huruf qalqalah baik dalam satu kalimat atau dua kalimat. ${ }^{12}$

\section{Perencanaan Pembelajaran Qira ah Muwaḥhadah}

Perencanaan berasal dari kata rencana yaitu pengambilan keputusan tentang apa yang harus dilakukan untuk mencapai tujuan. Dengan demikian, proses suatu perencanaan harus dimulai dari penetapan tujuan yang akan dicapai melalui analisis kebutuhan serat dokumen yang lengkap, kemudian menetapkan langkah-langkah yang harus dilakukan untuk mencapai tujuan tersebut. ${ }^{13}$ Ketika kita merencanakan maka pola pikir kita diarahkan bagaimana agar tujuan itu dapat di capai secara efektif dan efisien. Elly (1979), mengatakan bahwa perencanaan itu pada dasarnya adalah suatu proses dan cara berpikir yang dapat membantu menciptakan hasil yang diharapkan. Pendapat di atas menggambarkan, bahwa suatu perencanaan di awali dengan adanya target (hasil) yang harus dicapai, selanjutnya berdasarkan penetapan target tersebut dipikirkan bagaimana cara mencapainya. Sejalan dengan pendapat diatas Kaufman (1972) memandang bahwa perencanaan itu adalah sebagai suatu

\footnotetext{
${ }^{12}$ Unit Tahfidh MQ, Study Alquran Qiro ah Muwahhadah Versi Madrasatul Quran (Jombang: Unit Tahfidh Madrasatul Quran, 2003), 67.

${ }^{13}$ Wina Sanjaya, Perencanaan dan Desain Sistem Pembelajaran (Jakarta: Kencana, 2011), 24.
} 
Metode Qira Ah Muwahhadah Dalam Membentuk Keserasian...

proses untuk menetapkan" kemana harus pergi" mengandung pengertian sama dengan merumuskan tujuan dan sasaran yang akan dituju, sedangkan merumuskan bagaimana untuk sampai ke" tempat" itu dengan cara yang paling efektif dan efisien berarti menyusun langkah-langkah yang dianggap efektif dalam rangka pencapaian tujuan. $^{14}$

Sebelum memasuki proses pembelajaran Qira ah Muwaḥhadah, terlebih dahulu dirumuskan perencanaan pembelajaran Qira ah Muwaḥhadah sebagai berikut :

a. Melaksanakan ujian pengelompokan Alquran bagi santri baru.

b. Membuat kurikulum pembelajaran Alquran.

c. Membuat tata tertib bagi guru dan santri dalam pelaksanaa pembelajaran Alquran.

d. Membuat standart kelayakan guru Alquran (Ustadz). ${ }^{15}$

3. Proses Pembelajaran Qira ah Muwaḥhadah

Dalam pembelajaran Qira ah Muwaḥhadah perlu adanya metode pembelajaran yang sangat dibutuhkan dalam perwujudan memberikan pengajaran kepada santri yang belajar di Pondok Pesantren Madrasatul Qur an Tebuireng. Diantaranya dengan cara mengarahkan dan memberi contoh atau teladan yang baik kepada santri yang mempunyai niat memperbaiki bacaan Alquran, agar bisa membaca Alquran sesuai dengan kaidah-kaidah keilmuan Alquran yang benar.

Metode adalah cara yang digunakan untuk mengimplementasikan rencana yang sudah disusun dalam kegiatan nyata agar tujuan yang telah disusun tercapai secara optimal. ${ }^{16}$

Adapun beberapa metode yang bisa diterapkan dalam pembelajaran Alquran kepada santri antara lain:

a. Metode Ceramah

Metode ceramah dapat diartikan sebagai cara penyajian materi pelajaran melalui penuturan secara lisan atau penjelasan langsung kepada sekelompok siswa.

${ }^{14}$ Ibid., 25.

${ }^{15}$ Sumber Data: Dokumen dikutip di Kantor Unit Tahfidh, 15 Mei 2018

${ }^{16}$ Majid, Strategi Pembelajaran, 193

Falasifa, Vol. 10 Nomor 2 September 2019| 112 
Metode ini digunakan dalam beberapa kesempatan saja dengan maksud untuk memberikan pencerahan dan semangat kepada santri yang sedang belajar Alquran agar selalu fokus pada tujuan utamanya.

b. Metode Demonstrasi

Metode demonstrasi adalah metode penyajian mata pelajaran dengan memperagakan dan mempertunjukkan kepada santri tentang suatu proses, situasi atau benda tertentu yang tidak terlepas dengan penjelasan secara lisan oleh guru. Ilmu Alquran tidak bisa dipisahkan dengan adanya praktek atau demonstrasi baik yang dilakukan guru atau Ustadz dan juga santri itu sendiri. Seorang guru memberikan contoh bagaimana mengucapkan huruf dan ayat dalam Alquran yang benar dan dilanjutkan dengan praktek santri dalam menirukan bacaan yang telah dibacakan oleh guru tersebut.

c. Metode Problem Based Learning

Pembelajaran berbasis masalah merupakan inovasi dalam pembelajaran, karena dalam PBM kemampuan berfikir siswa betul-betul dioptimalisasikan melalui proses kerja kelompok atau individu yang sistematis. Sehingga siswa dapat memperdayakan, mengasah, menguji dan mengembangkan kemampuan berfikirnya secara berkesinambungan.

d. Metode Simulasi

Simulasi berasal dari kata simulate yang artinya berpura-pura atau seakan-akan menjadi sesuatu. Sebagai metode pembelajaran simulasi diartikan sebagai cara penyajian pengalaman belajar dengan menggunakan situasi tiruan untuk memahami tentang konsep, prinsip atau ketrampilan tertentu. ${ }^{17}$

Dalam simulasi pembelajaran Alquran diperlukan untuk memberikan stimulusstimulus dalam proses belajar Alquran, metode ini bisa dikaitkan dengan gerakan-gerakan untuk membantu proses belajar Alquran.

Sedangkan model pembelajaran diartikan sebagai kerangka konseptual yang digunakan sebagai pedoman dalam melakukan kegiatan. Model dapat dipahami sebagai desain (tipe) suatu deskripsi atau analogi yang dipergunakan

${ }^{17}$ Wina Sanjaya, Strategi Pembelajaran (Jakarta : Kencana, 2006), 145.

Falasifa, Vol. 10 Nomor 2 September 2019| 113 
Metode Qira Ah Muwahhadah Dalam Membentuk Keserasian...

untuk membantu proses visualisasi sesuatu yang tidak dapat diamati secara langsung. Model pembelajaran menurut Joyce dan Weil adalah suatu rencana atau pola yang dapat digunakan untuk membentuk kurikulum (rencana pembelajaran jangka panjang), merancang bahan-bahan pembelajaran, dan membimbing pembelajaran di kelas atau yang lain. ${ }^{18}$

Model pembelajaran Qira ah Muwaḥhadah merupakan penjelasan tentang bagaimana bentuk pembelajaran Alquran yang dipraktekkan oleh Pendiri Pondok Pesantren Madrasatul Quran Tebuireng, dengan tujuan untuk memberikan kemudahan dan mengarahkan santri dalam proses belajar membaca dan menghafal Alquran. Sedangkan model pembelajaran Alquran Qira ah Muwaḥhadah, yaitu:

1) Model klasikal, pembelajaran ini di fokuskan pada materi fas $\} a h a h$ dan penguasaan ilmu tajwid sesuai dengan tingkat kelompoknya masing-masing dengan menggunakan kurikulum yang telah ditentukan oleh unit tahfidh. Pembelajaran ini dilaksanakan setelah jama'ah sholat maghrib.

2) Model individual (setoran Alquran), para santri membaca Alquran dihadapan ustadz (guru) yang telah ditentukan dengan membawa data atau buku setoran Alquran. Pelaksanaan setoran Alquran ini dilaksanakan pada waktu $b a^{\prime} d a$ shubuh.

2) Model pembinaan hafalan Alquran. Program pembinaan hafalan Alquran dilaksanakan setelah jama ah sholat ashar dan bertempat di asrama santri masing-masing serta dibimbing langsung oleh Pembina kamar. Pembinaan ini dimaksudkan agar para santri sudah terbiasa sejak dini menghafalkan suratsurat pendek atau juz 30, 29 dan 28. ${ }^{19}$

Dengan cara ini diharapkan santri fas\}ih dan benar dalam membaca Alquran sesuai dengan kaidah-kaidah ilmu tajwid sebelum mereka memasuki proses menghafal Alquran. Sehingga harapannya ketika santri sudah resmi mengambil program tahfidhul Qur an tidak mengalami kesulitan.

\footnotetext{
${ }^{18}$ Rusman, Model-model Pembelajaran (Jakarta : Raja Grafindo Persada, 2012), 133.

${ }^{19}$ Sumber Data: Dokumen dikutip di Kantor Unit Tahfidh, 15 Mei 2018
}

Falasifa, Vol. 10 Nomor 2 September 2019| 114 
Sebagai syarat para santri Pondok Pesantren Madrasatul Qur an Tebuireng agar dapat mengikuti atau mengambil program tahfidhul Qur an adalah para santri harus sudah mampu membaca Alquran binnadhar dengan fas\}ih, lancar, dan telah memenuhi standart Qira ah Muwaḥhadah. Hal ini dimaksudkan agar para santri mudah dalam mengikuti program tahfidh. Karena orang yang menghafal Alquran akan tetapi dia kurang memahami dan menguasai bacaan Alquran binnadhar dengan baik, maka dia akan mengalami kesulitan dalam proses menghafal Alquran. Apalagi yang berhubungan dengan makharijul huruf, sifatul h\}uruf dan hukum bacaan Alquran.

Sedangkan tahapan-tahapan pembelajaran Qira ah Muwaḥhadah di Pondok Pesantren Madrasatul Qur an Tebuireng di bagi menjadi beberapa kelompok, yaitu naqis\} dan mubtadi' (pemula yaitu kelas D dan C), mutawassit\} (menengah yaitu kelas B), muntadzir (menunggu maqbul yaitu kelas A), dan maqbul (diterima program tahfidh kelas M). ${ }^{20}$

\section{Evaluasi Pembelajaran Qira ah Muwaḥhadah}

Secara harfiah kata evaluasi berasal dari bahasa inggris evaluation yang berarti penilaian atau penaksiran. Evaluasi adalah suatu proses yang sistematis dan berkelanjutan untuk menentukan kualitas (nilai dan arti) dari sesuatu, berdasarkan pertimbangan dan kriteria tertentu dalam rangka pembuatan keputusan. ${ }^{21}$

Tercapai tidaknya proses dalam pembelajaran Qira ah Muwaḥhadah dapat dilihat dari bagaimana hasil yang dicapai oleh santri yang belajar Alquran. Semakin baik proses pembelajaran Alquran yang dilakukan, maka sangat mempengaruhi hasil yang akan dicapai. Evaluasi dalam pembelajaran Qira ah Muwaḥhadah dilakukan secara berkala sesuai dengan tingkatan-tingkatan yang dicapai oleh santri tersebut. Dan secara umum pelaksanaan evaluasi pembelajaran Alquran Qira ah Muwaḥhadah dilaksanakan maksimal 6 bulan melalui ujian semester Alquran. ${ }^{22}$

\section{B. Keserasian Bacaan Alquran}

a. Pengertian serasi dalam bacaan Alquran

${ }^{20}$ Ibid., 18.

${ }^{21}$ Zainal Arifin, Evaluasi Pembelajaran (Bandung: Remaja Rosdakarya, 2016), 5.

${ }^{22}$ Litbang MQ, Buku Panduan Santri (Jombang: Madrasatul Quran Tebuireng, 2012), 10. 
Metode Qira Ah Muwahhadah Dalam Membentuk Keserasian...

Serasi dalam kajian Bahasa Indonesia mempunyai makna sesuai, selaras atau benar. $^{23}$

Adapun maksud dari keserasian dalam bacaan Alquran adalah serasi atau benar dalam hal fas $\}$ ih mengucapkan huruf-huruf hijaiyyah, serasi dalam hal praktek ilmu tajwid ketika membaca Alquran maupun serasi dalam irama atau lagu pada saat melantunkan bacaan ayat-ayat Alquran.

b. Kriteria keserasian bacaan Alquran

Kriteria keserasian dalam membaca Alquran yang di rumuskan oleh K.H.M. Yusuf Masyhar selaku pendiri Pondok Pesantren Madrasatul Qur an Tebuireng secara garis besar meliputi: serasi dalam bidang kefashihan mengucapkan makhorijul h)uruf, serasi dalam hal praktek ilmu tajwid ketika membaca Alquran maupun serasi dalam irama atau lagu pada saat melantunkan bacaan ayat-ayat Alquran.

Adapun kefas\}ihan dalam bacaan Alquran dapat diukur dalam pengucapan huruf-huruf hijaiyyah dan ayat-ayat Alquran sesuai dengan kaidah hukum tajwid. Hal ini sesuai dengan firman Allah pada surat Al Baqarah: 121

Orang-orang yang telah kami berikan Al kitab kepadanya, mereka membacanya dengan bacaan yang sebenarnya (QS. Al Baqarah (2):121). ${ }^{24}$

Sedangkan tujuan mempelajari ilmu tajwid adalah agar bacaan Alquran tersebut benar dan fashih dalam pengucapan huruf-huruf hijaiyyah dan ayat-ayat Alquran. Dengan demikian kefas\}ihan dalam bacaan Alquran harus sesuai dengan kaidah yang telah diajarkan oleh pendahulu-pendahulu kita yang sampai kepada kita dengan mutawatir.

c. Kualitas Bacaan Alquran

Kualitas bacaan seseorang ditentukan fashih dan tidaknya dalam melafadhkan ayat-ayat Alquran yang berpegang teguh pada kaidah-kaidah ilmu tajwid.

a. Pengertian Fas 3 ih

${ }^{23}$ Purwo Djatmiko, Kamus Lengkap Bahasa Indonesia (Surabaya: Anugerah, tt), 483.

${ }^{24}$ Departemen Agama Republik Indonesia, 574.

Falasifa, Vol. 10 Nomor 2 September 2019| 116 
Kata fas \}ih atau dalam bahasa Arab disebut (الفصاحة) al-Fas\}ahah artinya kata kerja tanpa waktu yaitu terang atau jelas. Kalimat itu dinamakan fas jih apabila kalimat itu terang pengucapannya, jelas artinya dan bagus susunannya. ${ }^{25}$

Fas lih tidaknya ucapan seseorang bisa dilihat pada saat melafadhkan atau pengucapan huruf-huruf hijaiyyah pada ayat Alquran. Hal ini dibutuhkan kejelasan suara yang dihasilkan dari lidah, mulut dan tenggorokan. Karena dengan kejelasan pengucapan ini yang menentukan baik tidaknya bacaan Alquran. seperti dalam kisah Nabi Musa dan Nabi Harun. Alquran menjelaskan dalam sebuah ayat:

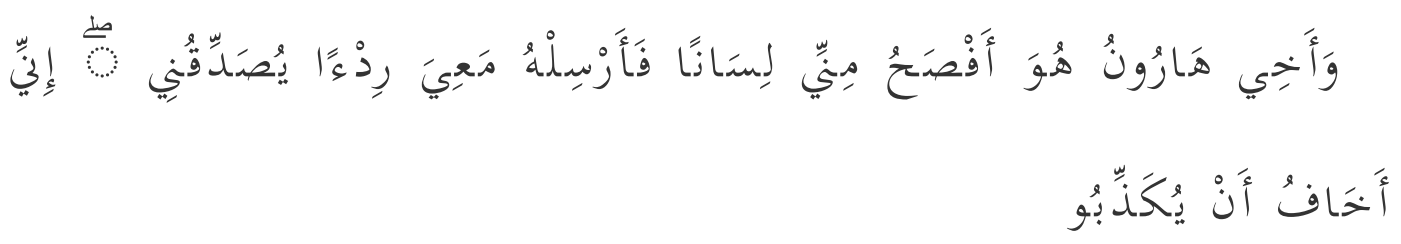

Artinya: Dan saudaraku Harun dia lebih fasih lidahnya dari padaku, Maka utuslah dia bersamaku sebagai pembantuku untuk membenarkan (perkataan)ku; Sesungguhnya Aku khawatir mereka akan mendustakanku". (Q.S. Al Qoshosh (28): 34$)$

b. Kriteria Kefas \}ihan Bacaan Alquran

Kefas\}ihan dalam bacaan Alquran dapat diukur benar atau tidaknya proses pengucapan ayat-ayat Alquran sesuai dengan kaidah yang ada dalam hukum ilmu tajwid.

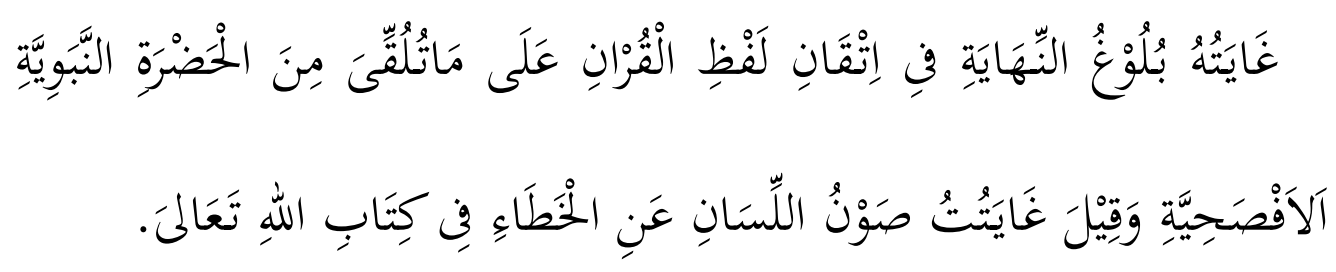

Artinya: Tujuan (mempelajari ilmu tajwid) adalah agar dapat membaca ayat-ayat Alquran secara betul (fashih) sesuai dengan yang diajarkan Rosulullah

${ }^{25}$ A. Zuhdi Muhdlor, Kamus Kotemporer Al 'Ashri Arab Indonesia Atabik Ali (Yogyakarta: Yayasan Ali Maksum PP Krapyak, 1996), 139. 
Metode Qira Ah Muwahhadah Dalam Membentuk Keserasian...

SAW, juga agar dapat memelihara lisan dari kesalahan-kesalahan ketika membaca Kitab Allah ta'ala (Alqur an). ${ }^{26}$

Kefas)ihan dalam bacaan Alquran harus sesuai dengan kaidah yang telah diajarkan oleh pendahulu-pendahulu kita yang sampai kepada kita dengan mutawatir. Kefas ihan dalam pembahasan qiro ah ini sesuai dengan qiro ah (bacaan) Imam Hafs An 'Ashim yang banyak dikenal di kawasan Asia Tenggara.

c. Tah\} sin Tilawah

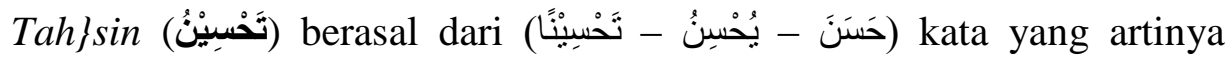
memperbaiki, membaguskan, menghiasi, mempercantik. Tilawah (تَلَاوَةُ) berasal

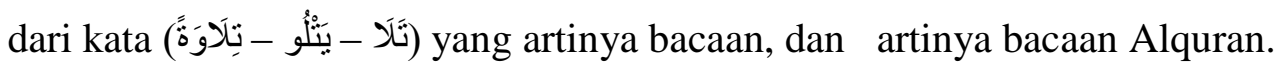

Tilawah menurut istilah:
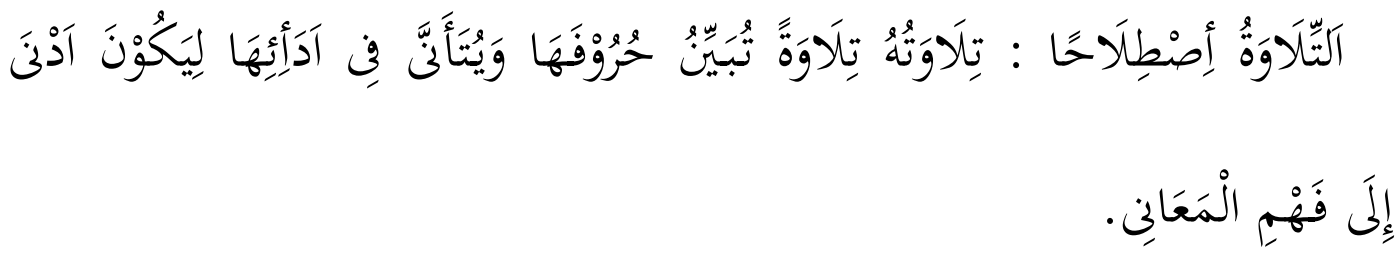

Artinya: membaca Alquran dengan bacaan yang menjelaskan hurufhurufnya dan berhati-hati dalam melaksanakan bacaannya, agar lebih mudah memahami makna yang terkandung didalamnya. ${ }^{27}$

Tah\} $\sin$ tilawah adalah upaya dalam memperbaiki dan membaguskan bacaan Alquran sesuai dengan kaidah ilmu tajwid. ${ }^{28}$

Sedangkan kiat-kiat dalam tah sin tilawah sebagai berikut:

1) Niat yang ikhlas

Niat adalah salah satu syarat diterimanya amal, niat akan menjadi motivator pada setiap tindakan yang akan dilakukan. Oleh karena itu proses tah $\}$ sinul qiro ah harus diniatkan sungguh-sungguh untuk mendapatkan ridlo Allah SWT.

2) Mempunyai keyakinan yang tinggi

\footnotetext{
${ }^{26}$ Muhammad Al Mahmud, Tuntunan Membaca Alquran dengan Benar (Surabaya: Al Hidayah, 2004), 2 .

${ }^{27}$ Ahmad Annuri, Panduan Tahsin Tilawah Alquran dan Ilmu Tajwid (Jakarta: Pustaka Al Kautsar, 2011), 3. ${ }^{28}$ Ibid., 5 .
}

Falasifa, Vol. 10 Nomor 2 September 2019| 118 
Allah berfirman:

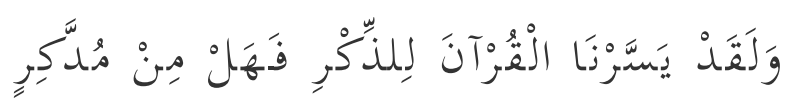

Artinya: Dan Sesungguhnya Telah kami mudahkan Al-Quran untuk pelajaran, maka adakah orang yang mengambil pelajaran? (Q.S. Al-Qomar (54): 17)

Tidak ada kemustahilan meskipun bukan orang Arab bisa mengucapkan Alquran dengan baik dan benar karena sudah dijanjikan dalam ayat tersebut diatas. Dan Alquran adalah bukan hanya tertuju pada orang Arab saja tetapi bersifat universal.

d. Talaqqi dan musyafah\}ah.

Mempelajari Alquran harus melalui seorang guru secara langsung berhadapan, karena apabila tidak dilakukan demikian maka sulit untuk mencapai bacaan yang benar. Karena bacaan itu ditentukan dengan contohcontoh yang bisa dijelaskan secara langsung oleh guru yang ahli qiro at. ${ }^{29}$

Adapun cara mempelajari Alquran yang efektif adalah:

a) Disiplin dalam membaca setiap hari

Kontinyu dalam membaca Alquran akan mempermudah dalam pengucapan karena apabila tidak terbiasa dengan bacaan Alquran lidah akan terasa kaku.

b) Membiasakan dengan satu jenis mushaf

Dengan memakai satu mushaf yang sama rasm usmani akan memudahkan kita dalam membaca Alquran karena dengan demikian, kita tidak bingung dengan tulisan yang berbeda.

c) Merasa terikat dengan menambah jumlah bacaan secara periodik.

Keterikatan dengan Alquran akan menjadikan minat belajar dan membaca Alquran kita akan terus bertambah setiap hari dengan menambah sedikit demi sedikit target bacaan setiap harinya.

d) Banyak mendengar bacaan murottal 
Metode Qira Ah Muwahhadah Dalam Membentuk Keserasian...

Mendengarkan kaset murottalan secara langsung akan menambah ghiroh (semangat) dan motivasi kita cinta terhadap Alquran.

e) Membuka diri untuk menerima nasihat

Bersedia dengan keterbukaan hati dalam menerima nasihat, kritikan dari teman ketika mengikuti kegiatan $\operatorname{tah}\}$ sin qiro'ah, karena terkadang kita juga salah dalam membaca Alquran. Sehingga dengan menerima masukan tersebut bisa menjadikan bacaan Alquran kita lebih baik lagi. ${ }^{30}$

\section{PEMBAHASAN}

\section{A. Perencanaan Pembelajaran Qira ah Muwaḥhadah di Pondok Pesantren Madrasatul Qur an Tebuireng}

Sebelum pelaksanaan pembelajaran, terlebih dahulu dirumuskan perencanaan pembelajaran, tujuannya agar proses pembelajaran lebih terarah dan hasil yang didapatkan akan lebih maksimal.

Perencanaan berasal dari kata rencana yaitu pengambilan keputusan tentang apa yang harus dilakukan untuk mencapai tujuan. Dengan demikian, proses suatu perencanaan harus dimulai dari penetapan tujuan yang akan dicapai melalui analisis kebutuhan serat dokumen yang lengkap, kemudian menetapkan langkah-langkah yang harus dilakukan untuk mencapai tujuan tersebut. ${ }^{31}$ Ketika kita merencanakan maka pola piker kita diarahkan bagaimana agar tujuan itu dapat di capai secara efektif dan efisien. Elly (1979), mengatakan bahwa perencanaan itu pada dasarnya adalah suatu proses dan cara berpikir yang dapat membantu menciptakan hasil yang diharapkan. Pendapat di atas menggambarkan, bahwa suatu perencanaan diawali dengan adanya target (hasil) yang harus dicapai, selanjutnya berdasarkan penetapan target tersebut dipikirkan bagaimana cara mencapainya. Sejalan dengan pendapat di atas Kaufman (1972) memandang bahwa perencanaan itu adalah sebagai suatu proses untuk menetapkan" kemana harus pergi" mengandung pengertian sama dengan merumuskan tujuan dan sasaran yang akan dituju, sedangkan merumuskan bagaimana untuk sampai ke" tempat" itu dengan cara yang

\footnotetext{
${ }^{30}$ Ibid., 20.

${ }^{31}$ Wina Sanjaya, Perencanaan dan Desain Sistem Pembelajaran (Jakarta: Kencana, 2011), 24.

Falasifa, Vol. 10 Nomor 2 September 2019| 120
} 


\section{Moch. Sya'roni Hasan}

Lusmiyatun Nisa

paling efektif dan efisien berarti menyusun langkah-langkah yang dianggap efektif dalam rangka pencapaian tujuan. ${ }^{32}$

Sesuai dengan perencanaan pembelajaran Alquran di Pondok Pesantren Madrasatul Qur an Tebuireng yang meliputi:

1. Melaksanakan ujian pengelompokan Alquran bagi santri baru

2. Membuat kurikulum pembelajaran Alquran

3. Membuat tata tertib bagi guru dan santri dalam pelaksanaan pembelajaran Alquran

4. Membuat standart kelayakan guru Alquran (Ustadz).

Menurut peneliti, dengan merumuskan perencanaan tersebut sudah tepat. Karena dengan adanya perencanaan dan rumusan-rumusan pembelajaran yang dijadikan pijakan dalam mengimplementasikan metode Qira ah Muwaḥhadah, maka proses pembelajarannya akan lebih terarah dengan hasil yang lebih maksimal, sehingga tujuan pembelajaran bisa tercapai sesuai dengan yang diharapkan.

\section{B. Proses Pembelajaran Qira ah Muwaḥhadah di Pondok Pesantren Madrasatul Qur an Tebuireng}

Sedangkan dalam proses pembelajaran dibutuhkan metode yang tepat untuk menerapkan rencana pembelajaran yang telah disusun sebelumnya. Metode adalah cara yang digunakan untuk mengimplementasikan rencana yang sudah disusun dalam kegiatan nyata agar tujuan yang telah disusun tercapai secara optimal. ${ }^{33}$

Adapun beberapa metode yang bisa diterapkan dalam pembelajaran Alquran kepada santri antara lain:

e. Metode Ceramah

Metode ceramah dapat diartikan sebagai cara penyajian materi pelajaran melalui penuturan secara lisan atau penjelasan langsung kepada sekelompok siswa. Metode ini digunakan dalam beberapa kesempatan saja dengan maksud untuk memberikan pencerahan dan semangat kepada santri yang sedang belajar Alquran agar selalu fokus pada tujuan utamanya.

\section{f. Metode Demonstrasi}

\footnotetext{
${ }^{32}$ Ibid., 25.

${ }^{33}$ Abdul Majid, Strategi Pembelajaran, (Bandung: Remaja Rosda Karya, 2014),193
}

Falasifa, Vol. 10 Nomor 2 September 2019| 121 
Metode Qira Ah Muwahhadah Dalam Membentuk Keserasian...

Metode demonstrasi adalah metode penyajian mata pelajaran dengan memperagakan dan mempertunjukkan kepada santri tentang suatu proses, situasi atau benda tertentu yang tidak terlepas dengan penjelasan secara lisan oleh guru. Ilmu Alquran tidak bisa dipisahkan dengan adanya praktek atau demonstrasi baik yang dilakukan guru atau Ustadz dan juga santri itu sendiri. Seorang guru memberikan contoh bagaimana mengucapkan huruf dan ayat dalam Alquran yang benar dan dilanjutkan dengan praktek santri dalam menirukan bacaan yang telah dibacakan oleh guru tersebut.

\section{g. Metode Problem Based Learning}

Pembelajaran berbasis masalah merupakan inovasi dalam pembelajaran, karena dalam PBM kemampuan berfikir siswa betul-betul dioptimalisasikan melalui proses kerja kelompok atau individu yang sistematis. Sehingga siswa dapat memperdayakan, mengasah, menguji dan mengembangkan kemampuan berfikirnya secara berkesinambungan.

h. Metode Simulasi

Simulasi berasal dari kata simulate yang artinya berpura-pura atau seakanakan menjadi sesuatu. Sebagai metode pembelajaran simulasi diartikan sebagai cara penyajian pengalaman belajar dengan menggunakan situasi tiruan untuk memahami tentang konsep, prinsip atau ketrampilan tertentu. ${ }^{34}$

Sedangkan metode Qira ah Muwaḥhadah di Pondok Pesantren Madrasatul

Qur an meliputi: pembinaan fas\}ahłah Alquran klasikal, setoran Alquran, dan pembinaan hafalan Alquran.

1. Pembinaan fas\}ah\}ah Alquran klasikal

Pembinaan fas\}ahłah Alquran klasikal di Pondok Pesantren Madrasatul Qur an dilaksanakan pada malam hari (ba'da maghrib). Pembinaan model seperti ini bertujuan agar santri dapat mengucapkan huruf-huruf Alquran dengan fashih dan benar sesuai dengan lah\}jah 'Arabiyah serta penguasaan ilmu tajwid dalam teori dan praktek. Tehnik pembelajaran fas\}ah\}ah ini diklasifikasikan dengan sistem cluster berdasarkan hasil seleksi baca Alquran pada awal penerimaan santri baru.

2. Setoran Alquran binnaḍhar (dengan membaca).

${ }^{34}$ Wina Sanjaya, Strategi Pembelajaran (Jakarta : Kencana, 2006), 145.

Falasifa, Vol. 10 Nomor 2 September 2019| 122 
Setoran Alquran dilaksanakan setiap hari kecuali hari Jum'at dan hari libur dengan alokasi waktu ba'da shubuh dengan tata cara sebagai berikut:

a) Setoran Alquran diawali dengan bacaan doa, ta'awud, basmalah dan diakhiri bacaan tas\}diq serta di tutup dengan do'a bersama yang dipimpin oleh ustadznya masing-masing.

b) Santri wajib mempersiapkan materi yang akan disetorkan, baik sebelum maupun ketika menunggu giliran untuk menghadap Ustadz.

c) Setiap kali menghadap Ustadz, santri membaca dihadapan ustadz sesuai dengan kurikulum setoran Alquran pada setiap tingkatan masing-masing

d) Ustadz menyimak bacaan Alquran satu persatu bagi santri baru dan dua orang santri serta memperhatikan dengan seksama fașahah, praktek ilmu tajwidnya maupun kelancarannya dan menegur jika terjadi kesalahan dengan memberi isyarat terlebih dahulu atau contoh bacaan yang benar.

e) Jika materi baru masih kurang dikuasai, Ustadz menyuruh untuk mengulangi materi bacaan tersebut pada pertemuan yang akan datang.

Peran guru dalam membimbing, mengarahkan dan menyimak penghafalpenghafal Alquran adalah sangat penting, karena hafalan sendiri tanpa diperdengarkan kepada guru kurang dapat dipertanggungjawabkan kebenarannya. Pada umumnya menghafalkan sendiri menurutnya sudah lancar, benar, sudah baik, sudah dapat dikuasai tanpa ada satu hurufpun yang keliru, ternyata setelah diperdengarkan ke guru masih saja ada yang kurang, sering terjadi kelupaan untuk mengaitkan ayat-ayat yang serupa awalnya tetapi tidak sama rangkaiannya. ${ }^{35}$

Dengan demikian peran Asatidz dalam membimbing, mengarahkan dan menyimak setoran bacaan santri Pondok Pesantren Madrasatul Quran Tebuireng adalah sangat penting dalam proses menjaga kualitas bacaan Alquran.

3. Pembinaan hafalan Alquran

Program pembinaan hafalan Alquran dilaksanakan setelah jama'ah sholat ashar dan bertempat di asrama santri masing-masing serta di bimbing langsung oleh Pembina kamar. Pembinaan ini dimaksudkan agar para santri sudah terbiasa sejak

${ }^{35}$ Muhaimin Zen. Tata Cara/Problematika Menghafal Al Qur'an dan Petunjuk-Petunjuknya. (Jakarta: Pustaka Al Huma, 1985), 137.

Falasifa, Vol. 10 Nomor 2 September 2019| 123 
Metode Qira Ah Muwahhadah Dalam Membentuk Keserasian...

dini menghafalkan surat-surat pendek atau juz 30, 29 dan 28 sebelum memasuki program tahfidh ( menghafal Alquran).

Menurut peneliti, dalam mengimplementasikan metode Qira ah Muwaḥadah dalam membentuk keserasian bacaan Alquran di Pondok Pesantren Madrasatul Qur an Tebuireng melalui tiga metode: Pembelajaran fas $\}$ ahah klasikal, setoran Alquran dan pembinaan hafalan Alquran. Hal ini sudah sesuai dengan metode pembelajaran Alquran pada saat Nabi Muhammad SAW menerima wahyu dari malaikat Jibril, yaitu Malaikat Jibril membacakan kemudian Nabi Muhammad SAW menirukan sampai betul-betul wahyu yang diturunkan dikuasai. Kemudian cara di turunkan wahyu secara bertahap. Hal ini sesuai dengan metode Qira ah Muwaḥhadah yang pembelajarannya sesuai dengan tahapan masing-masing dan disesuaikan dengan kemampuan santri. Sedangkan setoran Alquran yang dilaksanakan di Pondok Pesantren Madrasatul Qur an Tebuireng, hal ini juga sesuai dengan yang diajarkan Nabi Muhammmad SAW setelah menerima wahyu Allah kemudian setoran kepada malaikat jibril pada bulan Ramadhan. Dengan demikian metode Qira ah Muwaḥhadah yang dipraktekkan di Pondok Pesantren Madrasatul Qur an Tebuireng bertujuan menyiapkan santri bukan hanya fas jih dan benar dalam membaca Alquran. Akan tetapi sekaligus menyiapkan generasi - generasi calon penghafal Alquran dengan baik dan benar serta dapat dipertanggungjawabkan kualitas bacaan Alqurannya.

Sedangkan tahapan-tahapan pembelajaran Qira ah Muwaḥhadah di Pondok Pesantren Madrasatul Qur an terdiri dari lima tingkatan yang disesuaikan kemampuan dalam membaca Alquran:

a. Tingkat naqis\} adalah merupakan kelompok pengajian Alquran bagi santri yang belum mampu membaca Alquran dan belum mempunyai dasar-dasar fașaḥah serta belum mengenal ilmu tajwid. Mereka dibina secara klasikal (kelompok) dengan alokasi waktu dua kali pertemuan setiap hari, dengan kurikulum materi bacaan: kitab tilawati dan faṣaḥah juz 30 serta materi hafalan surat at Takatsur sampai an Nas.

b. Tingkat mubtadi' adalah kelompok pengajian Alquran bagi santri yang belum mampu membaca Alquran dan belum mempunyai dasar-dasar faṣaḥah dan ilmu

Falasifa, Vol. 10 Nomor 2 September 2019| 124 
tajwid yang belum baik. Mereka dibina secara klasikal (kelompok) dengan alokasi waktu dua kali pertemuan setiap hari, dengan kurikulum materi bacaan: faṣahah surat al-Baqarah dan juz 30 serta materi hafalan surat an Naba' sampai an Nas. Sedangkan materi tajwidnya meliputi: makharijul hłuruf, mad dan qashr, hukum nun mati atau tanwin, hukum mim dan nun tasydid.

Analisis peneliti, metode Qira ah Muwaḥhadah tingkat Naqis\} (D) dan tingkat Mubtadi' (C) menggunakan metode demonstrasi, yaitu ustadz memberikan contoh bacaan Alquran dengan memberikan petunjuk kepada santri dan memperagakan cara melafalkan makharijul h\}uruf.

Hal ini sesuai dengan teori Syaiful Sagala. Metode demontrasi adalah petunjuk tentang terjadinya suatu peristiwa atau benda sampai pada penampilan tinggah laku yang dicontohkan agar dapat diketahui dan dipahami oleh peserta didik secara nyata. ${ }^{36}$

c. Tingkat Mutawassit\} adalah diperuntukkan bagi santri yang sudah mampu membaca dengan fașhih dan lancar serta sudah bisa membaca Alquran dengan tartil. Akan tetapi belum mampu menguasai dan memahami waqaf dan ibtida' serta sifatul h\}uruf. Mereka dibina sebagaimana dua kali pertemuan setiap hari dengan kurikulum materi bacaan: surat Ali Imron sampai al An'am. Materi hafalannya: juz 29 dan juz 28. Sedangkan materi tajwidnya; waqaf dan ibtida', sifatul h\}uruf.

d. Tingkat Muntadzir, diperuntukkan bagi santri yang sudah menguasai dasar-dasar faṣahah, lancar membaca dan sudah dapat membaca Alquran dengan tartil, akan tetapi belum mampu dengan baik menjelaskan masing-masing sifatul hłuruf dan musykilatul ayat. Mereka dibina secara klasikal dua kali pertemuan setiap hari dengan kurikulum materi bacaan; surat al Anfal sampai al Isra'. Materi hafalannya: juz 28 dan surat Yasin, al Waqi'ah serta ar Rahman. Sedangkan materi tajwidnya meliputi; sifatul h\}uruf dan musykilatul ayat.

Menurut peneliti, metode Qira ah Muwaḥhadah tingkat Mutawassit\} dan Muntadzir dengan menggunakan metode problem based learning, yaitu ustadz sebagai pendamping dalam pembelajaran Alquran dan apabila terjadi kesalahan

${ }^{36}$ Abdul Majid. Strategi Pembelajaran. (Bandung: Remaja Rosda Karya, 2014), 197

Falasifa, Vol. 10 Nomor 2 September 2019| 125 
Metode Qira Ah Muwahhadah Dalam Membentuk Keserasian...

dalam bacaan Alquran, ustadz tidak langsung membenarkannya akan tetapi menunjuk salah satu santri untuk membenarkan bacaan tersebut berikut alasannya.

Hal ini sesuai dengan teori Tan problem based learning (pembelajaran berbasis masalah) adalah merupakan inovasi dalam pembelajaran, karena dalam PBM kemampuan berfikir siswa betul-betul dioptimalisasikan melalui proses kerja kelompok atau individu yang sistematis. Sehingga siswa dapat memperdayakan, mengasah, menguji dan mengembangkan kemampuan berfikirnya secara berkesinambungan. ${ }^{37}$

e. Tingkat maqbul atau kelas 'M' ini adalah kelas tertinggi di bidang pendidikan dan pembelajaran fas\}ah\{ah Alquran di lingkungan Pondok Pesantren Madrasatul Qur an. Kelompok atau kelas ini adalah diperuntukkan bagi santri yang sudah mampu membaca dengan fașih\} dan lancar serta sudah dapat membaca Alquran dengan tartil sesuai standart Qira ah Muwaḥhadah (standart bacaan Alquran Pondok Pesantren Madrasatul Qur an Tebuireng) dan sudah diizinkan mengambil program tahfidh ( menghafal Alquran) serta berhak diwisuda binnadhar pada bulan Desember.

Menurut peneliti, metode Qira ah Muwaḥhadah tingkat Maqbul (M) dengan menggunakan metode peer theaching, yaitu ustadz sebagai pendamping dalam pembelajaran Alquran dan menunjuk santri untuk memimpin dan memberikan contoh bacaan Alquran kepada teman-temannya. Dan apabila terjadi kesalahan dalam bacaan Alquran, ustadz tidak langsung membenarkannya akan tetapi menunjuk salah satu santri untuk membenarkan bacaan tersebut berikut alasannya.

Hal ini sesuai dengan teori peer theaching yaitu merupakan kegiatan pembelajaran yang dilakukan seorang siswa kepada siswa lainnya dan salah satu siswa itu lebih memahami materi pembelajaran. ${ }^{38}$

\section{Evaluasi Pembelajaran di Pondok Pesantren Madrasatul Qur an Tebuireng.}

\footnotetext{
${ }^{37}$ Rusman. Model-model Pembelajaran. (Jakarta: Raja Grafindo Persada, 2012), 229.

${ }^{38}$ Abdul Majid. Strategi Pembelajaran....,206

Falasifa, Vol. 10 Nomor 2 September 2019| 126
} 
Secara harfiah kata evaluasi berasal dari bahasa inggris evaluation yang berarti penilaian atau penaksiran. Evaluasi adalah suatu proses yang sistematis dan berkelanjutan untuk menentukan kualitas (nilai dan arti) dari sesuatu, berdasarkan pertimbangan dan kriteria tertentu dalam rangka pembuatan keputusan. ${ }^{39}$

Tercapai tidaknya proses dalam pembelajaran Qira ah Muwaḥhadah dapat dilihat dari bagaimana hasil yang dicapai oleh santri yang belajar Alquran. Semakin bagus proses pembelajaran Alquran yang dilakukan, maka sangat mempengaruhi hasil yang akan dicapai.

Sedangkan evaluasi pembelajaran Alquran Qira ah Muwaḥhadah Pondok Pesantren Madrasatul Qur an Tebuireng di laksanakan secara menyeluruh, baik evaluasi yang bersifat formal (ujian Alquran) maupun evaluasi yang berkaitan dengan proses pembelajaran Alquran Qira ah Muwaḥhadah dan kualitas yang dihasilkan (out put). Untuk evaluasi yang bersifat formal (ujian Alquran) dilaksanakan 6 bulan sekali atau per semester. Akan tetapi khusus untuk tingkatan naqis\} (kelas D) yang memakai kitab tilawati, ujiannya dilaksanakan minimal tiga bulan sekali. Dan untuk ujian seleksi maqbul dilaksanakan empat kali dalam setahun pada bulan (Maret, Juni, September dan Nopember). ${ }^{40}$

Evaluasi yang berkaitan dengan proses pembelajaran Alquran Qira ah Muwaḥhadah dan kualitas yang dihasilkan (out put) dilaksanakan maksimal tiga bulan sekali. Khusus untuk evaluasi yang dilaksanakan oleh pengurus unit tahfidh (bidang pembelajaran Alquran) di jadwal setiap bulan. Dengan demikian secara umum pelaksanaan evaluasi pembelajaran Alquran Qira ah Muwaḥhadah di Pondok Pesantren Madrasatul Qur an Tebuireng dilaksanakan maksimal 6 bulan melalui ujian semester Alquran.

Analisis peneliti, setiap proses pembelajaran harus diadakan evaluasi yang berkesinambungan. Hal ini bertujuan agar kelemahan-kelemahan yang timbul pada saat proses pembelajaran dapat diketahui, selanjutnya diadakan perbaikan dan dilengkapi

${ }^{39}$ Zainal Arifin, Evaluasi Pembelajaran (Bandung: Remaja Rosdakarya, 2016), 5.

${ }^{40}$ Litbang MQ, Buku Panduan Santri (Jombang: Madrasatul Quran Tebuireng, 2012), 10. 
Metode Qira Ah Muwahhadah Dalam Membentuk Keserasian...

sarana prasarana yang dapat membantu lancarnya proses pembelajaran. Dengan adanya evaluasi tersebut hasil dari pembelajaran diharapkan lebih maksimal. Maka sudah tepat apabila Pondok Pesantren Madrasatul Qur an Tebuireng melaksanakan evaluasi yang berkesinambungan dan menyeluruh agar outputnya lebih maksimal.

Adapun hasil yang didapatkan setelah dilakukan evaluasi pembelajaran Qira ah Muwaḥhadah adalah terbentuknya keserasian bacaan Alquran santri madrasatul Qur an Tebuireng. Sedangkan kriteria keserasian dalam membaca Alquran bagi santri Pondok Pesantren Madrasatul Qur an Tebuireng meliputi: pertama, serasi dalam bidang kefas\}ihłan dalam mengucapkan makharijul h\}uruf. Kedua, serasi dalam praktek ilmu tajwid ketika membaca Alquran. Ketiga, serasi dalam irama atau lagu pada saat melantunkan bacaan ayat-ayat Alquran.

Adapun yang dimaksud kefashihan dalam membaca Alquran, apabila seseorang benar dalam mengucapkan makharijul hjuruf pada bacaan ayat-ayat Alquran dan sesuai dengan kaidah ilmu tajwid. ${ }^{41}$

Hal ini sesuai dengan firman Allah pada surat Al Baqarah: 121

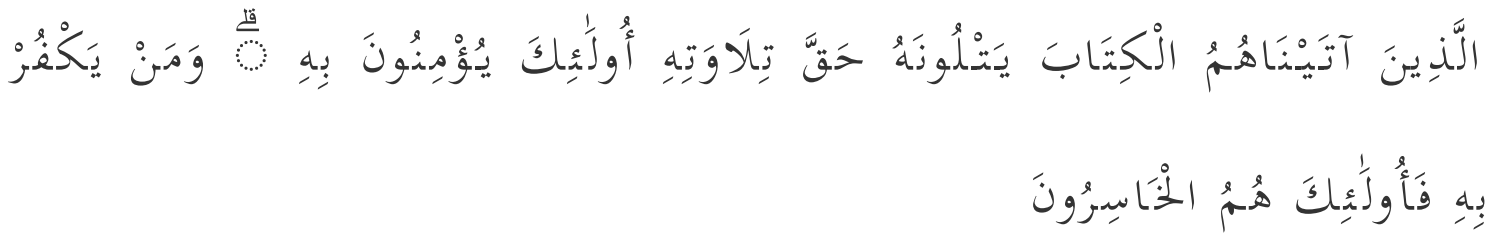

Artinya: Orang-orang yang telah kami berikan Al kitab kepadanya, mereka membacanya dengan bacaan yang sebenarnya. (QS. Al Baqarah:121).

Kriteria keserasian bacaan Alquran dalam praktek ilmu tajwid meliputi: hukum nun mati atau tanwin, hukum mim mati, hukum mad, sifatul h\}uruf dan musykilatul ayat.

Hal ini sesuai dengan firman Allah pada surat al Muzammil ayat 4

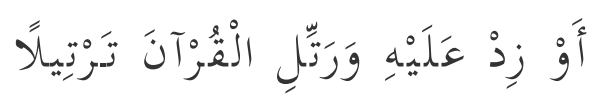

${ }^{41}$ H. A. Hariri Shoheh dkk. Panduan Ilmu Tajwid. (Jombang: Unit Tahfidh Madrasatul Qur an, 2012), 1.

Falasifa, Vol. 10 Nomor 2 September 2019| 128 
Artinya; Dan bacalah Alquran itu dengan perlahan-lahan (tartil).(QS. al Muzammil: 4)

Keserasian bacaan Alquran dalam hal irama atau lagu bagi santri Pondok Pesantren Madrasatul Qur an Tebuireng dengan mengikuti lagu yang dilantunkan oleh Syech Mahmud Khalil al Khushory pada saat membaca Alquran, yaitu dengan memilih lagu rost. Menurut K.H Damanhuri lagu rost ini termasuk kategori lagu yang sederhana dan tidak terlalu tinggi nadanya, sehingga dapat diresapi dalam melantunkan ayat-ayat Alquran. ${ }^{42}$

Menurut analisis peneliti, metode Qira ah Muwaḥhadah di Madrasatul Qur an Tebuireng ini telah berhasil membentuk bacaan Alquran para santri yang semula masih dipengaruhi oleh dialek daerah masing-masing menjadi serasi bacaan Alqurannya sesuai standart Qira ah yang diajarkan oleh K.H. M. Yusuf Masyhar, sehingga para santri Madrasatul Qur an Tebuireng bisa mengamalkan bacaan Alquran tersebut di daerahnya masing-masing, karena kemampuan bacaan Alquran yang dimiliki para santri, maka tidak heran jika banyak diantara santri Pondok Pesantren Madrasatul Qur an Tebuireng yang menjadi Imam di masjid daerah masing-masing. Hal ini terbukti pada saat pelaksanaan Musabaqoh Tilawatil Qur an (MTQ) baik itu tingkat Provinsi maupun Nasional pesertanya banyak dari santri Madrasatul Qur an dan mendominasi dalam perlombaan tersebut.

Sebagai bukti konkrit bacaan Alquran santri Pondok Pesantren Madrasatul Qur an Tebuireng ditingkat Internasional. Pada tahun 2008 Ustadz M. Azhar Yunus, berasal dari Watampone Sulawesi Selatan meraih prestasi I cabang 30 Juz bil ghoib yang diadakan di Iran. Selanjutnya pada tahun 2016 ustadz H. Sholahuddin Al Ayubi asal Jombang mendapatkan prestasi I cabang MHQ 30 juz MTQ internasional Asia Pasifik yang di selenggarakan Kedutaan Besar Arab Saudi dan pada tahun 2017 ustadz H. Nur Hasan Fadhil santri asal Jombang mendapatkan prestasi I cabang MHQ 20 juz internasional Asia Pasifik yang di selenggarakan Kedutaan Besar Arab Saudi pula. Prestasi ini membuktikan bahwa kemampuan bacaan santri Madrasatul Qur an merupakan yang sangat baik. Dengan demikian proses pembelajaran Alquran Qira ah

${ }^{42}$ M. Misbahul Munir. Pedoman Lagu-lagu Tilawatil Qur an (Surabaya: Apollo, 1997), 29.

Falasifa, Vol. 10 Nomor 2 September 2019| 129 
Metode Qira Ah Muwahhadah Dalam Membentuk Keserasian...

Muwaḥhadah sangat terbukti dalam membentuk keserasian bacaan Alquran bagi santri Pondok Pesantren Madrasatul Qur an Tebuireng.

\section{KESIMPULAN}

Perencanaan Pembelajaran Alquran di Pondok Pesantren Madrasatul Qur an Tebuireng meliputi:1). melaksanakan ujian pengelompokan Alquran bagi santri baru 2). membuat kurikulum pembelajaran Alquran 3). membuat tata tertib bagi guru dan santri dalam pelaksana pembelajaran Alquran 4). membuat standart kelayakan guru Alquran (Ustadz).

Proses Pembelajaran Alquran di Pondok Pesantren Madrasatul Qur an Tebuireng melalui metode Qira ah Muwaḥhadah yang dapat mendukung keserasian bacaan Alquran meliputi: pembinaan fas\}ah\}ah Alquran klasikal, setoran Alquran, dan pembinaan hafalan Alquran.

Evaluasi Pembelajaran Alquran Qira ah Muwaḥhadah di Pondok Pesantren Madrasatul Qur an Tebuireng dilaksanakan secara menyeluruh, baik evaluasi yang bersifat formal (ujian Alquran) maupun evaluasi yang berkaitan dengan proses pembelajaran Alquran Qira ah Muwaḥhadah dan kualitas yang dihasilkan (out put). Untuk evaluasi yang bersifat formal (ujian Alquran) dilaksanakan 6 bulan sekali atau per semester. Sedangkan hasil yang didapatkan setelah melaksanakan evaluasi pembelajaran Qira ah Muwaḥhadah adalah di ketahuinya out put para santri yaitu dapat membentuk tiga keserasian baca an Alquran yang meliputi: Pertama, serasi dalam bidang kefashihan dalam mengucapkan makharijul h\}uruf. Kedua, serasi dalam praktek ilmu tajwid ketika membaca Alquran. Ketiga, serasi dalam irama atau lagu saat melantunkan bacaan ayat-ayat Alquran.

\section{DAFTAR PUSTAKA}

An Nawawi, Imam. Mutiara Riyadhus Shalihin. Bandung: Mizan Pustaka, 2009. -------, At Tibyan fi Adab Hamalat Al Qur'an. Bandung: Maktabha darul bayan, 1985.

Al Qattan, Manna Khalil. Studi Ilmu Ilmu Alquran, diterjemahkan oleh Aminuddin. Bogor: Litera Antar Nusa, 2009.

Ash-Shaabuuniy, Muhammad Ali. Studi Ilmu Alquran. Bandung: Pustaka Setia, 1998.

Annuri, Ahmad. Panduan Tahsin Tilawah Alquran dan Ilmu Tajwid. Jakarta: Pustaka Al Kautsar, 2011.

Arifin, Imron. Penelitian Kualitatif. Malang: Kalimasada Press, 1996.

Falasifa, Vol. 10 Nomor 2 September 2019| 130 
Moch. Sya'roni Hasan

Lusmiyatun Nisa

Arikunto, Suharsimi. Prosedur Penelitian Suatu Pendekatan Praktek. Jakarta: Rineka Cipta, 2010.

Al Mahmud, Muhammad. Tuntunan Membaca Al qur an dengan Benar. Surabaya: Al

Hidayah, 2004.

Arifin, Zainal. Evaluasi Pembelajaran. Bandung: Remaja Rosdakarya, 2016.

Dimyati, dan Mudjiono. Belajar dan Pembelajaran. Jakarta: Rineka Cipta, 2006.

Djamarah, Syaiful Bahri. Psikologi Belajar. Jakarta. Rineka Cipta, 2011.

Departemen Agama RI, Al-Qur'an dan Terjemahnya. Semarang: Toha Putra, 1989.

Djatmiko Purwo, Kamus Lengkap Bahasa Indonesia. Surabaya: Anugerah,tt.

Hakim, Moh Nur. Metodologi Studi Islam. Malang: UMM Press, 2004.

Jazari, Imam. Jazariah. Surabaya: Al Hidayah, 1991.

Kementrian Agama RI. Mukadimah Al qur an dan Tafsirnya. Jakarta: Kemenag RI, 2012.

Litbang, MQ. Buku Panduan Santri. Jombang : Madrasatul Quran Tebuireng, 2012.

Unit, Tahfidh MQ. Arsip Tahfidh. Jombang : Madrasatul Quran Tebuireng, 2013.

--------, Study Alquran Qira'ah Muwahhadah Versi Madrasatul Quran. Jombang: Unit Tahfidh Madrasatul Quran, 2003.

Majid, Abdul. Strategi Pembelajaran. Bandung: Remaja Rosda Karya, 2014.

Muzadi, Hasyim. Bunga Rampai Mutiara Alquran. Jakarta: Jamiyyatul Qura' wal Hufadz, 2006.

Moleong, Lexy. J. Metodologi Penelitian Kualitatif. Bandung: Remaja Rosdakarya, 2000.

Muhdlor, A. Zuhdi. Kamus Kontemporer Al. 'Ashri Arab Indonesia Atabik Ali Yogyakarta: Yayasan Ali Maksum PP Krapyak, 1996.

Munir, M. Misbahul. Pedoman Lagu-lagu Tilawatil Qur an. Surabaya: Apollo, 1997.

Qaradhawi, Yusuf. Bagaimana berinteraksi dengan Alquran (terjemahan: Kalthur Suhradi). Jakarta: Al Kautsar, 2000.

Quasem. Memahami Alquran menurut Kaum Sufi. Jakarta: Pustaka Azzam, 2001.

Rusman. Model-model Pembelajaran. Jakarta : Raja Grafindo Persada, 2012.

Shaheh Hariri, dkk. Panduan Ilmu Tajwid Penuntun Cara Menghafal Alquran dengan Baik dan Benar. Jombang : Unit Tahfidh Madrasatul Quran, 2012.

Sagala, Syaiful. Konsep dan Makna Pembelajaran. Bandung : Alfabeta, 2010.

Sanjaya, Wina. Kurikulum dan Pembelajaran Teori dan Praktek. Jakarta: Prenada Media Group, 2009.

Sugiyono. Metode Penelitian Pendidikan. Bandung: Alfabeta, 2012.

Syihab, M. Quraisy. Tafsir Al Misbah Pesan, Kesan dan Keserasian Alquran. Jakarta: Lentera Hati, 2002.

-------, Membumikan Alquran. Fungsi dan Peran Wahyu Dalam Kehidupan Masyarakat, Bandung: Mizan, 2003.

Zen, Muhaimin. Tata cara/Problematika Menghafal Al Qur'an dan PetunjukPetunjuknya. Jakarta: Pustaka Al Huma, 1985.

Undang-Undang RI No. 20 Tahun 2003, Tentang Sistem Pendidikan Nasional. Bandung: Penerbit Citra Umbara. 
Metode Qira Ah Muwahhadah Dalam Membentuk Keserasian...

Falasifa, Vol. 10 Nomor 2 September 2019| 132 